Int. J. Electrochem. Sci., 11 (2016) 6922 - 6932,

\title{
Electrochemical Investigation of the Corrosion Resistance of Ti20Mo Alloys in Simulated Physiological Solution with Added Proteins for Biomaterial Application
}

\author{
D. Mareci ${ }^{1}$, B.M. Fernández-Pérez ${ }^{2}$, L.C. Trinca ${ }^{3, *}$, L. Fotea ${ }^{3}$, R.M. Souto ${ }^{2,4, *}$ \\ ${ }^{1}$ Technical University “Gheorghe Asachi” of Iasi, D.Mangeron, Iasi, 700050, Romania. \\ ${ }^{2}$ Department of Chemistry, Universidad de La Laguna, E-38205 La Laguna (Tenerife, Canary \\ Islands), Spain. \\ 3 "Ion Ionescu de la Brad" University of Agricultural Science and Veterinary Medicine, Faculty of \\ Horticulture, Science Department, 3, Mihail Sadoveanu Alley, Iaşi, 700490, Romania. \\ ${ }^{4}$ Institute of Material Science and Nanotechnology, Universidad de La Laguna, E-38200 La Laguna \\ (Tenerife, Canary Islands), Spain. \\ *E-mail: 1ctrinca@Yahoo.com, rsouto@ull.es
}

doi: $10.20964 / 2016.08 .24$

Received: 23 April 2016 / Accepted: 30 May 2016 / Published: 7 July 2016

Corrosion behaviour of the studied Ti20Mo alloy together with the currently used metallic biomaterials Ti6Al4V, and Ti6Al7Nb alloys was investigated for biomedical applications. All the samples were examined using electrochemical techniques: linear polarization curves and electrochemical impedance spectroscopy (EIS) in electrochemical media: Ringer's solution with proteins at $37{ }^{\circ} \mathrm{C}$. The passive behaviour for all the Ti samples is observed for Ringer's solution with proteins. The Ti20Mo alloy underwent spontaneous passivation, and exhibited more positive zero current potential $\left(E_{\mathrm{ZCP}}\right)$, and lower corrosion current densities $\left(j_{\text {corr }}\right)$ than Ti6Al4V, and Ti6Al7 Nb alloys. The Ti20Mo alloy appears to posses superior corrosion resistance in Ringer's solution with proteins than the Ti6Al4V, and Ti6Al7Nb biomaterials.

Keywords: Biomaterials; Ti20Mo alloy; Corrosion resistance; Ringer's solution with proteins; Potentiodynamic polarization; Electrochemical impedance spectroscopy; Scanning electron microscopy.

\section{$\underline{\text { FULLTEXT }}$}

(C) 2016 The Authors. Published by ESG (www.electrochemsci.org). This article is an open access article distributed under the terms and conditions of the Creative Commons Attribution license (http://creativecommons.org/licenses/by/4.0/). 